\title{
Agricultural research for development: Investing in Uzbekistan's future
}

\author{
Babadjanov Abdirashid Musaevich
}

Research Institute of Market Reforms, Tashkent, Uzbekistan; pirbobo@mail.ru

Received 14 November 2012; revised 15 December 2012; accepted 24 December 2012

\begin{abstract}
The paper addresses challenges on organization and funding of research and development (http://www.multitran.ru/c/m.exe?a=110\&t=42005 $27 \quad 2 \quad 1 \& s c=0$ R\&D) in the agricultural sector. The necessity of modernization and re-equipment of agricultural sector was validated, which is important sector in the economy of Uzbekistan. The paper covers issues on increasing investments in agricultural research, implementation of results of research work into the agriculture production, strengthening of innovative activities. Also, the possibility of non-state budgetary financing of scientific-research process in the agrarian sector was considered. Author's view is given on the main directions of science that need to be supported as a foundation of further development of agricultural R\&D and as a result the agricultural production.
\end{abstract}

Keywords: Agricultural Sector; Innovation; Scientific Research; Research Product; Farms; Agricultural R\&D

\section{INTRODUCTION}

The farm structure in Uzbekistan has changed with a series of agricultural reforms after the independence, while the government of Uzbekistan has strategically adopted a gradual approach to the market oriented economy. There are mainly three stages in the reforms, and the reform measures are ongoing by the Government.

Agricultural policy has been established through a series of Presidential decrees and resolutions Cabinet of Ministries; these have focused more on issues of economic and institutional restructuring, as well as production, and more attention is being paid to sustainability through development of research in the sector, which has facilitated the research and extension of areas under orchards, vineyards, vegetables, melons and gourds, and foraging crops.

Management of agricultural $R \& D$ is the responsibility of the Ministry of Agriculture and Water Resources (MAWR) which has branches in 12 provisions (regions) and in 160 districts within the country.

Agricultural research and extension is crucial to increase farmers' output and generating income in the country however, agricultural research and many of potential linkages and institutional arrangements are needed to be promoted by the government [1].

Even though the recent years Uzbekistan has increased its support to agricultural $\mathrm{R} \& \mathrm{D}$, overall funding remains below the budget required to sustain viable agricultural R\&D projects that intended running and future priorities.

Considering challenges, agricultural R\&D systems set as primary objectives addressing the issues in order to improve agricultural productivity, increase the quality and quantity of food through intensification and diversification of sustainable agriculture and to develop the knowledge for the strengthening agriculture production, develop of best genetic fund and new crop varieties. A priority cross-cutting issue is addressing the needs of vulnerable and low income groups minimising adverse effects of the above mentioned threats.

In this regard, the agricultural $R \& D$ system of the UARPC focuses joint efforts on three main goals of agricultural research:

1) Improving the well-being of the rural population, particularly vulnerable groups and those dependent on agriculture;

2) Guaranteed improvement of the quality and quantity of nutritious food through the intensification and diversification of agriculture;

3) Rational use of natural resources;

\section{MAIN PLAYERS OF AGRICULTURAL R\&D IN UZBEKISTAN}

The principal agricultural R\&D agency is the Uzbek Agricultural Research and Production Center (UARPC), which does research on agriculture sector under the Ministry of Agriculture and Water Resources (MAWR) of 


\section{Uzbekistan.}

The most majority of agricultural R\&D in Uzbekistan is carried out by 45 research institutes and research stations of the UARPC and research labs in Universities.

Each institute and research station under UARPC has researchers to conduct agriculture $\mathrm{R} \& \mathrm{D}$ or agricultural advisory services based on extension principles with the respective subjects across the country.

The UARPC, which does research on agriculture sector assists the national government in formulating agricultural policies and conduct research related to crops, livestock, technical crops, husbandry, farming innovations, postharvest.

UARPC functions in introduction of R\&D:

MAWR and UARPC elaborate the program of research based system in farming and livestock to increase soil fertility, yield of agricultural crops and livestock output;

Introduce agricultural $R \& D$ innovated by institutions of the UARPC in farming, livestock, technical crops;

Provides with stock seeds of cereals, rice, cotton, vegetables, forage and other crops seed-growing farms;

Introduce science and research achievements into agriculture production.

\section{CHALLENGES OF AGRICULTURAL RESEARCH FOR DEVELOPMENT OF THE UARPC}

\subsection{Subsidies}

UARPC receives government subsidies to conduct its operations because it is not commercialized and does not charge for its services to cover operating costs, therefore main challenge is to secure with financial resources and capacities between the macro level agencies and the provinces.

\subsection{Outreach Programmes}

Implementing intended outreach programmes or research and extension services for farmers is challenging duty. Efforts are being started to strengthen UARPC's innovative significance and effectiveness under the government's new arrangement and economic growth priorities. Similar processes are being pursued in taking into consideration of the government's strategy to devolve Universities and Research stations of UARPC to the provinces.

\subsection{Innovations}

In agriculture research and extension services for innovative activities are still very weak, therefore it is necessary to develop an information services and agribusiness cutting-edge technologies as well as to develop ca- pacity of experts with relevant qualification and knowledge.

\subsection{Organization and Management}

Lack of Public Private Partnership in agricultural R\&D;

Insufficiency of system commitment;

Inadequacy of correspondence between state functions and routine activities;

Lack of coordination among agricultural extension service organizations and research centers.

\subsection{Scientific Approach/Manuals}

Too much technical;

Not farmer friendly;

No ad-hoc method;

Not location specific.

\section{FUNDING FOR AGRICULTURAL R\&D}

After Soviet period, government funding level towards to agricultural research significantly dropped (less than $0.1 \%$ of GDP) making it difficult to attract qualified specialists and young graduates from agricultural colleges to agriculture related jobs. Thus, agricultural practices are not backed by research causing decrease in crop production. However, recent years funding for agricultural R\&D in Uzbekistan slightly increased ( $0.2 \%$ of GDP).

Funding for agricultural R\&D in Uzbekistan is derived from a variety of sources, including national and state budgets, donors, and producer organizations. Unfortunately, the available data did not allow for a detailed analyze of spending private sector for agricultural R\&D. According to survey of author [2] the data did, however, reveal that governments remain by far the most important source of funding for public agricultural R\&D in the country.

We can see the Table 1 shows that dynamics of financing from state budget and out of budget for agricultural R\&D regularly have increased from 2001 to 2011. Moreover, amount of foreign investments (grants) has increased from 2001 till 2005. However, last five years the amount of foreign grants sharply decreased in 2007 and 2008. Nevertheless, since 2009 the amount of foreign grants has been increasing.

Here, the Table 2 shows that allocated funds for the scientific-research works for grain production consists $32.9 \%$ and for the cotton production consists $53.9 \%$ but allocated funds between cotton and vegetable, gourd, potato production consists $8.1 \%$ hence, here we can see the relatively bigger differences of allocated funds between cotton and vegetable, gourd, potato production.

Nowadays, it is undoubtedly evident that support to development of agricultural production is only possible 
Table 1. Dynamics of funds spent for agricultural R\&D.

\begin{tabular}{|c|c|c|c|c|c|c|c|c|c|c|c|c|}
\hline \multirow{2}{*}{ Indicators } & \multicolumn{11}{|c|}{ Years } & \multirow{2}{*}{$\begin{array}{c}\text { Relatively to } \\
\text { 2001-2011 } \\
\%\end{array}$} \\
\hline & 2001 & 2002 & 2003 & 2004 & 2005 & 2006 & 2007 & 2008 & 2009 & 2010 & 2011 & \\
\hline $\begin{array}{l}\text { Budget funds mln, Uzbek } \\
\text { soums }\end{array}$ & 674.7 & 953.0 & 801.7 & 916.8 & 1055.0 & 1360.4 & 1805.0 & 2624.0 & 5689.7 & 7606.2 & 10116.3 & 1127.3 \\
\hline Compared to total (\%) & 50.3 & 38.8 & 32.0 & 28.0 & 18.5 & 24.5 & 31.4 & 63.2 & 58.5 & 74.2 & & - \\
\hline $\begin{array}{l}\text { Funds out of budget } \\
\text { mln, Uzbek soums }\end{array}$ & 450.0 & 848.1 & 1364.0 & 1996.4 & 3884.6 & 4067.5 & 3869.0 & 1445.0 & 3792.7 & 2454.8 & 2944.7 & 545.5 \\
\hline Compared to total (\%) & 33.6 & 34.5 & 54.5 & 61.0 & 68.1 & 73.4 & 67.4 & 34.8 & 23.9 & 23.9 & & - \\
\hline $\begin{array}{l}\text { Foreign investments } \\
\text { (grants) mln, Uzbek } \\
\text { soums }\end{array}$ & 214.4 & 654.8 & 333.9 & 357.1 & 757.7 & 109.3 & 64.4 & 80.5 & 193.7 & 193.7 & 204.6 & 90.3 \\
\hline Compared to total (\%) & 16.0 & 26.6 & 13.3 & 10.9 & 13.3 & 2.0 & 1.1 & 1.9 & 1.9 & 1.9 & & - \\
\hline $\begin{array}{l}\text { Total spent funds } \\
\text { mln, Uzbek soums }\end{array}$ & 1339.1 & 2455.9 & 2499.6 & 3270.3 & 5697.3 & 5537.2 & 5738.4 & 4149.5 & 9740.1 & 10254.7 & 13265.6 & 765.8 \\
\hline
\end{tabular}

Source: Uzbek Agricultural Research and Production Center.

Table 2. Share of separate branches of crop growing in the agricultural production and financing of R\&D (2011).

\begin{tabular}{lcc}
\hline Branches of crop production & $\begin{array}{c}\text { Share of branches of crop production in } \\
\text { gross agricultural output (\%) }\end{array}$ & $\begin{array}{c}\text { Allocated funds for the } \\
\text { scientific-research works (\%) }\end{array}$ \\
\hline Grain growing & 21.3 & 32.9 \\
Cotton growing & 25.6 & 53.9 \\
Horticulture and viticulture & 16.6 & 36.5 \\
$\begin{array}{l}\text { Vegetables, watermelon, melon, and gourd } \\
\text { cultivation and potato growing }\end{array}$ & $\mathbf{1 0 0 . 0}$ \\
Total: & $\mathbf{8 . 1}$ \\
\hline
\end{tabular}

Source: Calculated according to the data provided by the Uzbek agricultural research and production center.

through development of scientifically intense production based on scientific products [3]. In this regard, the government must give priority on the following main perspective directions of science, which require support as a basis for further development of scientifically strong agricultural production:

- For development of agricultural R\&D for agricultural production to identify priority directions, which will be financed directly and through development of other adjacent structures;

- To finance scientific-research works on sustainable agriculture, agronomic practices required for farming;

- To identify adaptation of climate change including arid climate, social structures, institutional capacity, knowledge and education;

- To assist in development of modern technologies and conditions on creation of best local selection variety of crops and breeds of domestic animals with the use of best genetic fund.

\section{INCREASING INVESTMENTS IN AGRICULTURAL RESEARCH AND INNOVATION}

Although increased investment in agricultural research is not the only requirement for its strengthening, it re- mains the most significant factor in successful transformation processes.

Funding for agricultural research is sourced both from the public and the private sectors, and includes projects and programs funded by donors where this is possible.

Nowadays many international donor organizations and research and development centres are operating in the country. In addition, many projects are funded by governments of developed countries and international financial institutions. Technical assistances and funds of foreign taxpayers are disseminated in national development processes, including in agriculture, and satisfying in various degrees the needs of agricultural research, capacity building/education and extension systems. However, these efforts are fragmented, and majority of implementing activities are based on a programme approach. It is therefore necessary to focus efforts in the country on improving mechanism of donor coordination. [4].

Creating a mechanism for coordination among donors would greatly increase expected outcomes, bridging between segments of agriculture. As a result coordinating donors' activities, the return on financial and technical assistance would be sharply increased and the gaps between agricultural production, research, education, and 
extension will be reduced [5].

In line with the estimated increase in investments in agricultural research for development, the following actions should be undertaken:

- Assessment of existing and projected needs in agricultural research, funds required to conduct them;

- Identifying sources of funding for different categories of expenditure for research activities;

- Increasing financial recognition of the vital contribution of agricultural scientists to economic growth;

- Minimizing taxes on funds for research activities;

- Introducing a system to stimulate and to reward development-oriented scientific achievements; simplifying procedures for obtaining patents and copyrights on scientific developments, and improving rewards and the commission fee system for the use of scientific inventions [6];

- Applying tax incentives for private companies involved in funding their activities of research institutions, agricultural consulting agencies and extension systems.

\section{CONCLUSIONS}

Agricultural research for development should take into account multifunctional modern agriculture, and its influence on implementation of key social, demographic, environmental activities. In this comprehensive approach agricultural research should justify budget expenditures for agricultural development, demonstrate the contribution of agricultural sector in the national economy and lay the foundations for its innovative growth.

Enhanced research and extension systems will assist farmers in making economic and innovative decisions on improving productivity, introducing new technologies, and enhance elasticity to economic and climate crises impacts through improved information management, application of agricultural research for development.

The changing and strengthening of agricultural research for development requires participatory coordination and awareness by research institutions and organizations of the ongoing $R \& D$ activities and creating ena- bling environment for continuous improvement of scientific and professional capacity material and technical resources for development and promotion of demanddriven innovations in agriculture and in associated areas of science.

In the close future, the state will continue to dominate agricultural R\&D in the country, however, the private sector could be demonstrated its ability to successfully increase agricultural productivity. Therefore government should start to create policies that encourage private -sector enterprises to invest in R\&D and elaborate successful cooperation between the public and private sectors.

The UARPC would encourage both agricultural innovation transfer and agribusiness advices.

This innovative system promises to integrate agricultural producers and farmers into market oriented agricultural economy. To achieve result the UARPC should require government commitment, institutional leadership and staff capacity to develop fully this innovative agricultural research for development.

\section{REFERENCES}

[1] Babadjanov, A.M. (2010) Main directions of scientific support to agricultural sector in Uzbekistan during development of farms. Economics and Finances, 1, 36-38.

[2] Babadjanov, A.M. (2007) Improvement of financing of agricultural science. Agricultural-Manufacturing Complex: Economics, Management, 3, 12.

[3] Babadjanov, A. (2006) Main directions of scientific research, promote the development of farming in Uzbekistan. Scientific and Practical Journal, 21, 6.

[4] Bagrinovsky, K.A. (2003) Problems of management in development of scientifically intense production. Management in Russia and Abroad, 2, 57-71.

[5] Ogloblin, E. (2005) Development of research institutions and their activities in a condition of market economy. Nauka, Moscow, 32 p.

[6] Zuev, S.Y. (2008) On the problem of qualitative identification of scientifically intense production. Economics, 2, 122. 